\title{
List of Plates, Maps and Tables
}

PLATES

facing page

1. Seals of King Stephen and the Empress

By courtesy of the Trustees of the British Museum, and of the Mansell Collection

2. A Battle Scene

By courtesy of the Pierpont Morgan Library, New York

3. Geoffrey, Count of Anjou

Pbotograph by Giraudon, Paris

4. Henry of Blois

By courtesy of the Trustees of the British Maseum

MAPS

I. Castles held for Stephen and the Empress, I I 42-3

page

2. Castles held for Stephen and the Empress, I I 46-7

3. Duke Henry's Itinerary, I I 3

90

TABLES

I 9

x. Stephen's Danegeld Exemptions in 1130

page

2. Earls and Earldoms

3. Principal Participants in the Civil War, 1 1 36-53

4. The Chronicle Sources

I45

s. Genealogical Table

I 5 I

at end 
